\title{
IMPACT OF THE ORGANISATION OF MEGA SPORTING EVENTS ON SELECTED ELEMENTS OF THE TOURISM SECTOR
}

\author{
KRYSTIAN ZAWADZKI \\ Gdansk University of Technology, Faculty of Management and Economics, Department of Economic \\ Analysis and Finance
}

\begin{abstract}
Mailing address: Krystian Zawadzki, Gdansk University of Technology, Faculty of Management and Economics, Department of Economic Analysis and Finance, 11/12 Narutowicza Street, 80-233 Gdańsk, Poland, tel.: +48583486013, e-mail: kza@zie.pg.gda.pl
\end{abstract}

\begin{abstract}
Introduction. In the world-wide literature, there is no unanimity in the assessment of the impact of mega sporting events on the tourism sector. Therefore, the main purpose of this study was to quantify the impact of mega sporting events on changes in tourist inflow and the amount of expenditure incurred by visitors. Material and methods. In this study, an ex-post analysis of many different categories of mega sporting events was carried out in the context of their impact on selected aspects of the tourism sector in host countries. The study examined events organised in the years 1996-2014 classified into one of four categories: the Summer Olympic Games (SOG), the Winter Olympic Games (WOG), the Football World Cup (FIFA), and the European Football Championship (UEFA). The approach adopted made it possible to analyse the impact of sporting events on the tourism sector over 15 years. Data on both the inflow of tourists and the expenditure generated by them were taken from a single source - reports of the United Nations World Tourism Organization (UNWTO). Results. The results obtained are characterised by ambiguity, although the study identified the categories of sporting events and the sporting event phase in which clearly positive or negative effects on the tourism sector could be observed. Conclusions. The difficulty in confirming unambiguously positive, tangible effects on the tourism sector resulting from the organisation of mega sporting events makes it problematic to justify the commitment of large expenditure to preparing and conducting these events. It is necessary to look for other, intangible benefits related to the organisation of these events. It also seems appropriate to continue the research undertaken in the future on the basis of data disaggregated at the regional level.
\end{abstract}

Key words: sporting events, tourist inflow, long-term tourism, Olympic Games, football

\section{Introduction}

One of the most common reasons for the organisation of mega sporting events is the expected positive impact on the host economy. Favourable effects of the organisation of mega sporting events include benefits emerging in the tourism industry [1-4]. These include in particular the increase in the inflow of foreign tourists to the host country both in the event year and also in the years following the event [5]. Such positive effects in the tourism sector resulting from the organisation of sporting events are explained on the one hand by the increased media exposure of a given host country, and on the other, by favourable recommendations from tourists visiting at the time of the event itself. At the same time, it is expected that an increase in the number of visitors will translate into the inflow of new income to the host country's economy [6]. This is money spent by tourists on consumption that influences the creation of socalled "indirect effects" in connection with the organisation of mega sporting events [7]. Money from tourists also has direct effects (through the purchase of tickets to the event) and secondary effects [8].

Hence, the main aim of this paper is not only an assessment of the relationship between the organisation of mega sporting events and changes in tourist inflow in the host countries, but also a quantification of the impact of mega sporting events on the amount of expenditure incurred by visitors during the time frame of the event.
It should be emphasised that the conclusions from research carried out to date indicate that this relationship does not have to be exclusively positive [9]. On the one hand, the scale of benefits revealed during the organisation of the event focuses on the potential increase in tourist flow and consumption expenditure. This applies to those visitors who would never have visited a given place if not for the organisation of a mega sporting event. Some authors, however, pay attention to the risks associated with the crowding-out effect. This term was first used by R. Baade and V. Matheson in the context of tourist flow during mega sporting events in relation to the Olympic Games in Sydney in 2000 [10]. In this case, the tourist crowding-out effect led tourists who had intended to visit the host country to cancel or choose a different destination because of the fact that the mega sporting event was being organised. Residents, in turn, often leave the city or limit their expenses for the duration of the event. There are many reasons for this situation, the most common ones being concerns regarding crowded roads, communication problems, lack of accommodation, and safety issues [3]. Due to the crowding-out effect, the host economy loses money that would have been spent by residents and potential visitors. This means that, in fact, for the host economy, the organisation of mega sporting events can create both positive and negative effects associated with the tourism sector. The prevalence of the latter makes it difficult to estimate the net benefits caused by tourist flow at the time of mega sporting events. 


\section{Materials and methods}

In this study, an ex-post analysis of many different categories of mega sporting events was carried out in the context of their impact on selected aspects of the tourism sector in host countries. The study analysed events organised in the years 1996-2014 classified into one of four categories:

- Summer Olympic Games (SOG);

- Winter Olympic Games (WOG);

- Football World Cup (FIFA);

- European Football Championship (UEFA).

The choice of events in the period given was determined by the availability of source materials. Data regarding both the inflow of tourists and the expenditure generated by them were taken from a single source - reports of the United Nations World Tourism Organization [11]. It is one of the few institutions that publish aggregated detailed information on what is broadly understood as tourist flow, for all countries of the world. The statistical material acquired covered the years 1995-2014.

The increasing number of projects implemented due to the process of organising mega sporting events means that the preparation phase lasts for years and that the potential effects of the event are spread over time, many years after the event has finished. The only appropriate solution is therefore to adopt a specific time interval (a so-called event time window) for each event, which would cover all stages of the event: the preparatory phase (phase 1), the phase of the event itself (phase 2), and the phase after the event (phase 3). Although estimating the impact in a shorter period is simpler, since it is easier to distinguish the effects of the event, such an approach does not allow for a comprehensive account of the impact of the organisation of sporting events on the host. This is the reason why the main research focus is directed towards long-term effects, referred to as the legacy of mega sporting events [4, 12-15].

Estimating the legacy of mega sporting events in the dimension of time proves to be an equally complex issue. While it is easy to determine the starting point for the analysis, which can be the moment of announcing the intention to put forward the candidature, the candidate phase, or the moment the event host is announced, the challenge for researchers is to determine the end point for the estimates carried out in the phase after the event. A number of ex-post studies have shown that the impact of the event on the host decreases each year and disappears completely a few years after the event ends. For example, Preuss and Weiss, as well as Kang and Perdue, recognise that the effects of an event last about 10 years after its completion [16, 17]. For comparison, Sterken believes that the impact of an event in the phase after it has ended lasts no longer than 7 years [18].

In the analysis presented, the time interval for the event held in year $n$ was seven years before its start $(n-7)$ and seven years after its end $(n+7)$. This allowed the pre-event period to cover the entire preparatory phase for the largest events (SOG, WOG, and FIFA World Cup), and in the case of UEFA Euro, it also included the candidate phase. At the same time, the assumption was made that only the announcement of the host of a sporting event could cause changes in the tourism sector in connection with the organisation of the event. Finally, the approach adopted makes it possible to analyse the impact of sporting events on the tourism sector over 15 years. Adopting such a long period of observation allows the determination of not only the direction and strength of any potential dependence, but also the permanence of the changes observed, constituting the legacy of mega sporting events. In the case of some of the events analysed, however, research covering the entire period including all three stages of the event was not possible due to the limited time scope of source data obtained from the UNWTO. In this case, the analyses fully covered at least two of the three phases of the event, including the event phase itself (phase 2).

In terms of the variables analysed, longer-term visitors from abroad who stayed in a given country longer than one day were selected. In other words, same-day visitors were excluded; they may have constituted a large group of visitors during the event phase itself, yet due to the scale of their spending, their importance should be considered minor. It is obvious that longerterm visitors, even only with regard to the need for accommodation, leave more money in the host country. The expenditure of same-day visitors is generally lower than the one-day average for longer-term tourists [3]. Due to the expected benefits for the economy, greater importance should therefore be attributed to longer-term tourist visits.

In the assessment of the relationship between the organisation of a mega sporting event and changes in regard to tourist inflow and expenditure generated by tourists, an econometric model using multivariate regression was applied. The data analysis was carried out with estimation by the classic least squares method using the Gretl program. In assessing the effects of mega sporting events, significant importance is given to the binary variable included in the vector of explanatory variables. This made it possible to isolate the determinants associated with a particular phase of the event from the set of observations.

Due to the time span of the study, all amounts related to expenditure were harmonised by taking the value of the US dollar from the last year of the analyses (2014).

\section{Results}

In Figure 1, the darker colour indicates the extent of the tourist inflow and the amount of expenditure incurred by tourists in the time window of the sporting event (from year $t-7$ to year $t+7$ ). For distinction, the same variables were presented in a clear colour in the period extending beyond the time interval of the event. In order to distinguish the event year (year $t$ ), a checked pattern was used.

Considering both the extent of the tourist inflow and the expenditure incurred by foreign tourists in host countries in 1995-2014, a general upward trend can be seen. In most cases, in the primary period of observation (1995), the analysed values were the lowest, and then started to rise, reaching the highest level at the end of the observation (2014). The category of the mega sporting event or the moment when it was organised did not matter.

Limiting the observations to the time window of the event, the results are ambiguous, especially in terms of the extent of the inflow of foreign tourists. Apart from the events in which there was a regular, almost yearly increase in the number of longer-term visitors (FIFA Germany 2006 and UEFA Austria 2008), there are those whose organisation resulted in a smaller inflow of tourists during the event year (SOG Greece 2004 and WOG USA 2002), or those in which there was a decrease in the number of visitors in the preparatory phase (WOG Italy 2006 and WOG Canada 2010) or in the phase after the event (UEFA Portugal 2004 and SOG USA 1996).

The difficulties in defining a uniform trend in the number of tourists visiting are confirmed by the dynamics of changes in tourist inflow to the host countries presented in Table 1. Remaining solely in the event year, it is possible, on the one hand, to indicate such host countries organising mega sporting events in which the dynamics of the tourist inflow in year $t$ compared 
to year $t-1$ were positive and at the same time the highest, considering the entire time window of the event (SOG 2000, WOG 2006, and UEFA 2008). On the other hand, there were cases of host countries for which the dynamics of the tourist inflow in year $t$ compared to year $t-1$ were negative and at the same time the lowest, considering the entire time window of the event (WOG 1998 and WOG 2002). In the case of the winter event in 2002, the most likely reason for the decline was the WTC terrorist attack in September 2001.

Also, in the long-term, that is in the entire phase after the event, the results were characterised by large variation. Apart from countries where in the consecutive years of this phase, an increase in the tourist inflow was observed (i.e., ZIO Japan 1988), there were hosts where the number of tourists remained relatively stable (i.e., Euro Great Britain 1996) and even dropped (i.e., LIO USA 1996), despite the aforementioned global upward trend in this regard.

Indicators of the dynamics of the amount spent by foreign tourists are characterised by generally positive values in the short-term (Tab. 2). Only in four cases did expenditure in the year of the event (year $t$ ) turn out to be lower than in the last year of the preparatory phase (year $t-1$ ). This happened three times in the case of host countries organising the Winter Olympics (Japan 1998, USA 2002, and Russia 2014), the differences always being significant, and once in the case of the host of the FIFA World Cup (South Korea 2002). In all other cases, in the year of the event, an increase in the dynamics of the expenditure of foreign tourists was observed. However, in no host country was this increase the highest, considering the annual changes covering the entire event time window.

It is significant that in the long term, the amount of expenditure of tourists increased. Almost always, the amount of expenditure of foreign tourists in year $t+7$ increased compared to year $t-7$, and, at the same time, it was the largest in the entire time window of the sporting event. However, there are some exceptions to this rule. A good example is Ukraine, a co-host of Euro 2012. Due to unexpected political turmoil in the second year following the end of the tournament, the amounts spent by foreign tourists decreased by more than $68 \%$, while the number of visitors decreased by half during the same time.

The regression analysis points to the negative impact of sporting events on both the inflow of tourists and the amount spent by visitors in the preparatory phase. This is indicated by the negative values of the coefficient for all the results characterised by statistical significance $(\mathrm{p}<0.1)$. Looking at
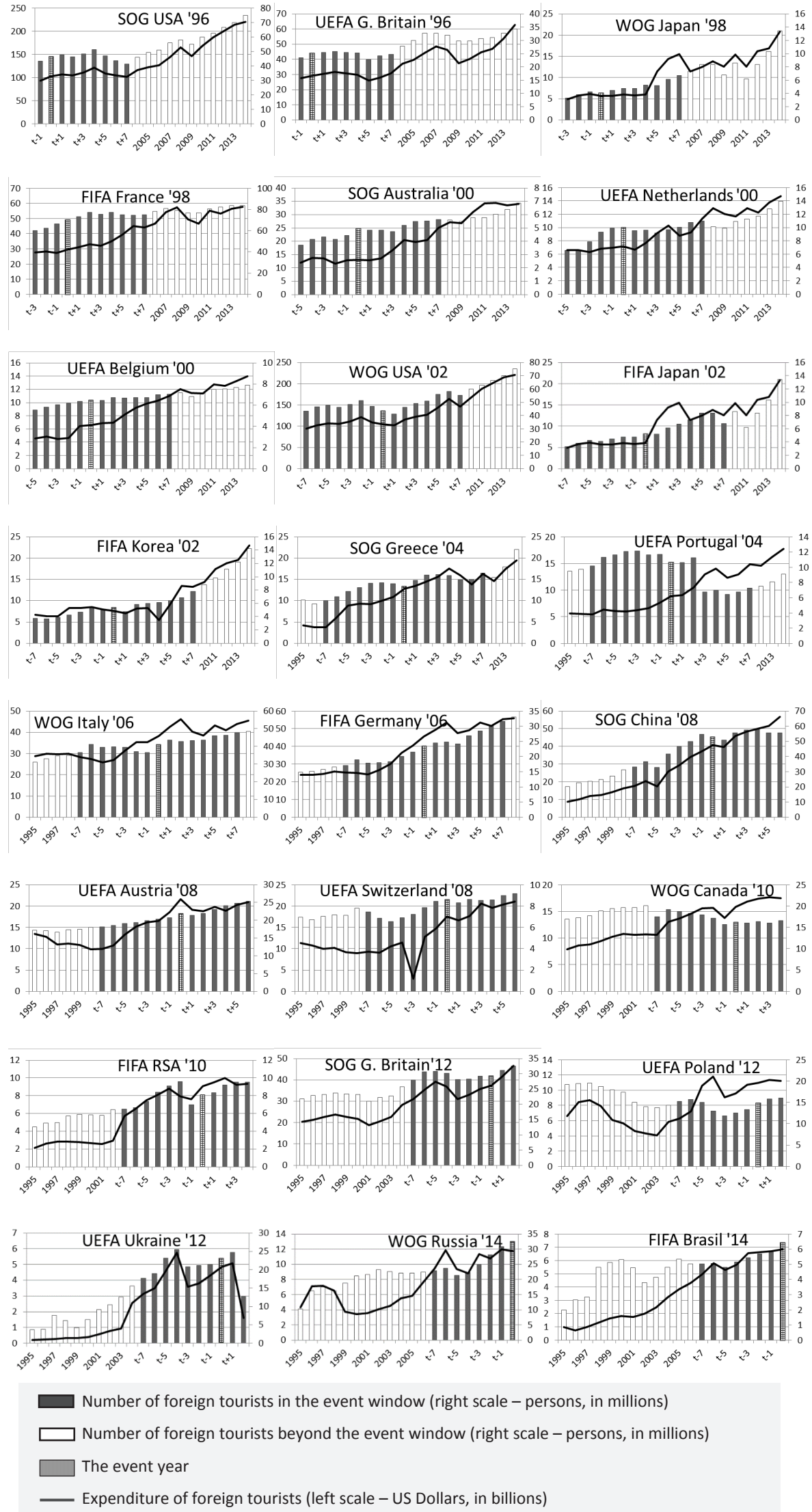

Source: Author's own based on UNWTO reports (11 with annexes)

Figure 1. The extent of the tourist inflow and the amount of expenditure by foreign tourists in the countries hosting mega sporting events 
Table 1. Dynamics of changes in the number of foreign tourists visiting in the time windows of mega sporting events based on UNWTO reports [11 with annexes]

\begin{tabular}{|c|c|c|c|c|c|c|c|c|c|c|c|c|c|c|c|c|}
\hline \multirow[b]{2}{*}{$\begin{array}{c}\text { Event } \\
\text { category }\end{array}$} & \multirow[b]{2}{*}{$\begin{array}{l}\text { Host country } \\
\text { and year }\end{array}$} & \multicolumn{7}{|c|}{ Phase 1a } & Phase $2^{b}$ & \multicolumn{7}{|c|}{ Phase 3c } \\
\hline & & $\begin{array}{c}t-7 / t-8 \\
{[\%]}\end{array}$ & $\begin{array}{c}t t-6 / t-7 \\
{[\%]}\end{array}$ & \begin{tabular}{|c|}
$t-5 / t-6$ \\
{$[\%]$}
\end{tabular} & $\begin{array}{c}t-4 / t-5 \\
{[\%]}\end{array}$ & $\begin{array}{c}t t-3 / t-4 \\
{[\%]}\end{array}$ & $\begin{array}{c}t-2 / t-3 \\
{[\%]}\end{array}$ & $\begin{array}{c}t-1 / t-2 \\
{[\%]}\end{array}$ & $\begin{array}{c}t / t-1 \\
{[\%]}\end{array}$ & $\begin{array}{c}t+1 / t \\
{[\%]}\end{array}$ & $\begin{array}{c}t+2 / t+1 \\
{[\%]}\end{array}$ & $\begin{array}{c}t+3 / t+2 \\
{[\%]}\end{array}$ & $\begin{array}{c}t+4 / t+3 \\
{[\%]}\end{array}$ & $\begin{array}{c}t+5 / t+4 \\
{[\%]}\end{array}$ & $\begin{array}{c}t+6 / t+5 \\
{[\%]}\end{array}$ & $\begin{array}{c}t+7 / t+6 \\
{[\%]}\end{array}$ \\
\hline \multirow{5}{*}{$\begin{array}{l}\text { Summer } \\
\text { Olympic } \\
\text { Games }\end{array}$} & USA 1996 & n.d. & n.d. & n.d. & n.d. & n.d. & n.d. & n.d. & 7,3 & 2,7 & $-2,9$ & 4,6 & 5,6 & $-8,4$ & $-7,1$ & $-5,4$ \\
\hline & Australia 2000 & n.d. & n.d. & n.d. & 10,4 & 3,7 & $-3,5$ & 7,0 & 10,6 & $-1,6$ & $-0,3$ & $-2,0$ & 9,9 & 5,5 & 0,6 & 2,0 \\
\hline & Greece 2004 & 9,1 & 8,4 & 11,4 & 7,7 & 7,3 & 0,9 & $-1,5$ & $-4,7$ & 10,9 & 8,6 & 0,8 & $-1,4$ & $-6,4$ & 0,6 & 9,5 \\
\hline & China 2008 & 6,2 & 11,0 & $-10,4$ & 26,7 & 12,1 & 6,6 & 9,6 & $-3,1$ & $-4,1$ & 9,4 & 3,4 & 0,3 & $-3,5$ & $-0,1$ & n.d. \\
\hline & G. Britain 2012 & 9,2 & 9,3 & 0,7 & $-2,4$ & $-6,4$ & 0,3 & 3,6 & $-0,1$ & 6,1 & 5,0 & n.d. & n.d. & n.d. & n.d. & n.d. \\
\hline \multirow{5}{*}{$\begin{array}{l}\text { Winter } \\
\text { Olympic } \\
\text { Games }\end{array}$} & \begin{tabular}{|l|} 
Japan 1998 \\
\end{tabular} & n.d. & n.d. & n.d. & n.d. & n.d. & 14,7 & 9,9 & $-2,7$ & 8,1 & 7,2 & 0,3 & 9,8 & $-0,5$ & 17,8 & 9,6 \\
\hline & USA 2002 & n.d. & 7,3 & 2,7 & $-2,9$ & 4,6 & 5,6 & $-6,4$ & $-7,1$ & $-5,4$ & 11,8 & 6,8 & 3,6 & 10,1 & 3,3 & $-5,0$ \\
\hline & Italy 2006 & 4,5 & 12,2 & $-3,9$ & 0,6 & $-0,5$ & $-6,4$ & $-1,5$ & 12,4 & 6,3 & $-2,1$ & 1,2 & 0,9 & 5,7 & 0,5 & 2,9 \\
\hline & Canada 2010 & $-12,6$ & 9,2 & $-2,0$ & $-2,7$ & $-1,8$ & $-4,4$ & $-8,2$ & 3,1 & $-1,3$ & 2,1 & $-1,7$ & 3,0 & n.d. & n.d. & n.d. \\
\hline & Russia 2014 & 1,9 & 3,3 & $-9,9$ & 4,4 & 11,9 & 13,0 & 9,3 & 5,3 & n.d. & n.d. & n.d. & n.d. & n.d. & n.d. & n.d. \\
\hline \multirow{6}{*}{$\begin{array}{l}\text { FIFA } \\
\text { World Cup }\end{array}$} & France1998 & n.d. & n.d. & n.d. & n.d. & n.d. & 4,0 & 6,7 & 5,3 & 4,3 & 5,5 & $-2,6$ & 2,4 & $-2,6$ & $-0,8$ & 0,7 \\
\hline & South Korea 2002 & n.d. & $-1,8$ & 6,1 & 8,8 & 9,6 & 14,2 & $-3,3$ & 3,9 & $-11,1$ & 22,4 & 3,5 & 2,2 & 4,8 & 6,9 & 13,5 \\
\hline & Japan 2002 & n.d. & 14,7 & 9,9 & $-2,7$ & 8,1 & 7,2 & 0,3 & 9,8 & $-0,5$ & 17,8 & 9,6 & 9,0 & 13,8 & 0,0 & $-18,7$ \\
\hline & Germany 2006 & 3,7 & 10,9 & $-5,9$ & 0,6 & 2,4 & 9,4 & 6,8 & 9,6 & 3,6 & 1,9 & $-2,7$ & 11,0 & 5,6 & 7,2 & 3,7 \\
\hline & RSA 2010 & 1,2 & 2,7 & 10,3 & 13,9 & 8,3 & 5,5 & $-26,9$ & 15,1 & 3,3 & 10,2 & 3,8 & 0,1 & n.d. & n.d. & n.d. \\
\hline & Brasil 2014 & 0,2 & 0,5 & $-4,9$ & 7,5 & 5,3 & 4,5 & 2,4 & 10,6 & n.d. & n.d. & n.d. & n.d. & n.d. & n.d. & n.d. \\
\hline \multirow{8}{*}{$\begin{array}{l}\text { European } \\
\text { Football } \\
\text { Champi- } \\
\text { onship }\end{array}$} & G. Britain 1996 & n.d. & n.d. & n.d. & n.d. & n.d. & n.d. & n.d. & 6,9 & 1,4 & 0,9 & $-1,4$ & $-0,7$ & $-9,4$ & 5,9 & 2,2 \\
\hline & Belgium 2000 & n.d. & n.d. & n.d. & 4,8 & 3,6 & 2,4 & 3,1 & 1,4 & $-0,1$ & 4,2 & $-0,4$ & 0,3 & 0,6 & 3,7 & 0,7 \\
\hline & Netherlands 2000 & n.d. & n.d. & n.d. & 0,1 & 19,2 & 18,8 & 6,0 & 1,3 & $-5,0$ & 1,0 & $-4,3$ & 5,1 & 3,8 & 7,3 & 2,5 \\
\hline & Portugal 2004 & 4,5 & 11,0 & 3,0 & 4,0 & 0,6 & $-4,3$ & 0,5 & $-9,1$ & $-0,3$ & 6,3 & $-39,8$ & 2,6 & $-7,5$ & 4,9 & 7,5 \\
\hline & Switzerland 2008 & $-4,7$ & $-7,9$ & $-4,9$ & 5,5 & 5,0 & 8,8 & 7,4 & 1,9 & $-3,6$ & 4,0 & $-1,1$ & 0,4 & 4,7 & 2,1 & n.d. \\
\hline & Austria 2008 & 1,1 & 2,4 & 2,5 & 1,6 & 3,0 & 1,6 & 2,5 & 5,6 & $-2,6$ & 3,0 & 4,6 & 4,9 & 2,7 & 1,9 & n.d. \\
\hline & Poland 2012 & 6,4 & 3,1 & $-4,4$ & $-13,5$ & $-8,3$ & 4,9 & 7,1 & 11,2 & 6,5 & 1,3 & n.d. & n.d. & n.d. & n.d. & n.d. \\
\hline & Ukraine 2012 & 12,8 & 7,4 & 22,1 & 10,1 & $-18,3$ & 1,9 & 1,0 & 7,5 & 7,2 & $-48,5$ & n.d. & n.d. & n.d. & n.d. & n.d. \\
\hline
\end{tabular}

a - preparatory phase (years from $t-7$ till $t-1$ ), b - the phase of the event itself (year $t$ ), ${ }^{\mathrm{c}}-$ the phase after the event (years from $t+1$ till $t+7$ ), n.d. - data not available.

Source: Author's own based on UNWTO reports (11 with annexes).

Table 2. Dynamics of changes in the amount of expenditure incurred by foreign tourists in the time windows of mega sporting events based on UNWTO reports [11 with annexes]

\begin{tabular}{|c|c|c|c|c|c|c|c|c|c|c|c|c|c|c|c|c|}
\hline \multirow{2}{*}{$\begin{array}{l}\text { Event } \\
\text { category }\end{array}$} & \multirow{2}{*}{$\begin{array}{l}\text { Host country } \\
\text { and year }\end{array}$} & \multicolumn{7}{|c|}{ Phase 1a } & \multirow{2}{*}{\begin{tabular}{|c|} 
Phase $2^{b}$ \\
$t / t-1$ \\
{$[\%]$}
\end{tabular}} & \multicolumn{7}{|c|}{ Phase $3^{c}$} \\
\hline & & $\begin{array}{c}\mathrm{t}-7 / \mathrm{t}-8 \\
{[\%]}\end{array}$ & $\begin{array}{c}\mathrm{t}-6 / \mathrm{t}-7 \\
{[\%]}\end{array}$ & $\begin{array}{c}\mathrm{t}-5 / \mathrm{t}-6 \\
{[\%]}\end{array}$ & $\begin{array}{c}t-4 / t-5 \\
{[\%]}\end{array}$ & $\begin{array}{c}\mathrm{t}-3 / \mathrm{t}-4 \\
{[\%]}\end{array}$ & $\begin{array}{c}\mathrm{t}-2 / \mathrm{t}-3 \\
{[\%]}\end{array}$ & \begin{tabular}{|c|}
$t-1 / t-2$ \\
{$[\%]$}
\end{tabular} & & $\begin{array}{c}t+1 / t \\
{[\%]}\end{array}$ & $\begin{array}{c}\mathrm{t}+2 / \mathrm{t}+1 \\
{[\%]}\end{array}$ & $\begin{array}{c}t+3 / t+2 \\
{[\%]}\end{array}$ & $\begin{array}{c}t+4 / t+3 \\
{[\%]}\end{array}$ & $\begin{array}{c}t+5 / t+4 \\
{[\%]}\end{array}$ & $\begin{array}{c}\mathrm{t}+6 / \mathrm{t}+5 \\
{[\%]}\end{array}$ & $\begin{array}{c}t+7 / t+6 \\
{[\%]}\end{array}$ \\
\hline \multirow{5}{*}{$\begin{array}{l}\text { Summer } \\
\text { Olympic } \\
\text { Games }\end{array}$} & USA 1996 & n.d. & n.d. & n.d. & n.d. & n.d. & n.d. & n.d. & 9,0 & 4,7 & $-1,8$ & 6,1 & 9,5 & $-9,8$ & $-4,3$ & $-2,8$ \\
\hline & Australia 2000 & n.d. & n.d. & n.d. & 15,6 & $-0,6$ & $-14,8$ & 10,3 & 1,2 & $-1,6$ & 6,4 & 22,2 & 22,9 & $-3,6$ & 3,5 & 22,6 \\
\hline & Greece 2004 & 0,9 & 63,1 & 42,8 & 4,8 & $-0,5$ & 8,6 & 8,4 & 18,1 & 5,0 & 7,7 & 8,2 & 12,1 & $-8,9$ & $-13,5$ & 17,3 \\
\hline & China 2008 & 9,6 & 14,6 & $-14,6$ & 47,9 & 13,8 & 15,9 & 9,7 & 9,7 & $-2,9$ & 15,5 & 5,8 & 3,2 & 3,3 & 10,2 & n.d. \\
\hline & G. Britain 2012 & 9,8 & 13,7 & 11,3 & $-5,7$ & $-16,1$ & 6,4 & 8,5 & 4,4 & 11,9 & 11,9 & n.d. & n.d. & n.d. & n.d. & n.d. \\
\hline \multirow{5}{*}{$\begin{array}{l}\text { Winter } \\
\text { Olympic } \\
\text { Games }\end{array}$} & Japan 1998 & n.d. & n.d. & n.d. & n.d. & n.d. & 18,0 & 6,9 & $-8,3$ & 0,9 & 4,5 & $-3,7$ & 5,5 & 89,1 & 25,0 & 8,4 \\
\hline & USA 2002 & n.d. & 9,0 & 4,7 & $-1,8$ & 6,1 & 8,5 & $-9,8$ & $-4,3$ & $-2,8$ & 13,9 & 5,5 & 3,9 & 13,8 & 14,2 & $-11,4$ \\
\hline & Italy 2006 & $-4,9$ & $-3,0$ & $-6,1$ & 4,1 & 16,3 & 13,2 & $-0,2$ & 8,3 & 11,5 & 8,3 & $-12,6$ & $-4,8$ & 12,5 & $-5,3$ & 7,0 \\
\hline & Canada 2010 & $-0,8$ & 22,9 & 4,8 & 6,6 & 7,2 & 0,4 & $-12,4$ & 15,3 & 6,3 & 3,4 & 1,4 & $-1,0$ & n.d. & n.d. & n.d. \\
\hline & Russia 2014 & 23,8 & 25,4 & $-20,9$ & $-5,7$ & 28,3 & $-5,0$ & 11,4 & $-1,9$ & n.d. & n.d. & n.d. & n.d. & n.d. & n.d. & n.d. \\
\hline \multirow{6}{*}{$\begin{array}{l}\text { FIFA } \\
\text { World } \\
\text { Cup }\end{array}$} & France 1998 & n.d. & n.d. & n.d. & n.d. & n.d. & 2,8 & $-3,4$ & 7,6 & 5,9 & 5,2 & $-2,1$ & 8,8 & 12,5 & 14,0 & $-2,1$ \\
\hline & South Korea 2002 & n.d. & $-4,8$ & $-0,5$ & 30,8 & 0,9 & 2,3 & $-7,1$ & $-3,8$ & $-8,1$ & 17,4 & 0,8 & $-34,3$ & 70,2 & 45,2 & $-1,2$ \\
\hline & Japan 2002 & n.d. & 18,0 & 6,9 & $-8,3$ & 0,9 & 4,5 & $-3,7$ & 5,5 & 89,1 & 25,0 & 8,4 & $-26,1$ & 8,1 & 10,9 & $-9,0$ \\
\hline & Germany 2006 & $-0,3$ & 2,0 & 5,2 & $-2,0$ & $-1,4$ & $-2,6$ & 6,9 & 8,4 & 13,8 & 8,4 & 9,4 & 8,0 & 8,3 & $-11,1$ & 3,2 \\
\hline & RSA 2010 & 95,4 & 14,0 & 15,4 & 8,0 & 8,1 & $-9,4$ & $-4,2$ & 19,2 & 4,7 & 5,1 & $-7,5$ & 1,0 & n.d. & n.d. & n.d. \\
\hline & Brasil 2014 & 14,8 & 16,8 & $-8,3$ & 7,5 & 15,0 & 1,4 & 0,9 & 2,1 & n.d. & n.d. & n.d. & n.d. & n.d. & n.d. & n.d. \\
\hline \multirow{8}{*}{$\begin{array}{l}\text { European } \\
\text { Football } \\
\text { Champi- } \\
\text { onship }\end{array}$} & G. Britain 1996 & n.d. & n.d. & n.d. & n.d. & n.d. & n.d. & n.d. & 5,8 & 4,5 & 3,9 & $-2,7$ & $-2,7$ & $-12,8$ & 6,4 & 10,5 \\
\hline & Belgium 2000 & n.d. & n.d. & n.d. & 6,5 & $-6,5$ & 2,1 & 40,0 & 1,9 & 4,5 & 0,7 & 18,1 & 12,4 & 6,9 & 4,7 & 6,8 \\
\hline & Netherlands 2000 & n.d. & n.d. & n.d. & $-0,2$ & $-4,1$ & 7,9 & 2,7 & 3,2 & $-6,8$ & 14,9 & 18,8 & 12,5 & $-14,9$ & 5,7 & 22,0 \\
\hline & Portugal 2004 & $-1,3$ & $-2,9$ & 15,3 & $-5,7$ & $-0,3$ & 3,4 & 5,4 & 13,6 & 13,8 & 2,0 & 13,7 & 19,0 & 8,0 & $-14,0$ & 4,9 \\
\hline & Switzerland 2008 & 3,4 & $-1,9$ & 15,1 & 8,7 & $-74,1$ & 335,9 & 14,5 & 19,4 & $-5,2$ & 5,7 & 17,2 & $-5,0$ & 3,7 & 3,3 & n.d. \\
\hline & Austria 2008 & 0,5 & 8,6 & 23,2 & 13,8 & 7,2 & 1,7 & 12,4 & 16,6 & $-11,4$ & $-2,1$ & 5,4 & $-4,3$ & 6,8 & 3,4 & n.d. \\
\hline & Poland 2012 & 7,6 & 15,4 & 46,4 & 11,6 & $-23,4$ & 5,7 & 12,1 & 2,4 & 3,3 & $-1,0$ & n.d. & n.d. & n.d. & n.d. & n.d. \\
\hline & Ukraine 2012 & 22,1 & 11,5 & 31,9 & 25,5 & $-38,0$ & 5,9 & 13,4 & 12,8 & 5,0 & $-68,3$ & n.d. & n.d. & n.d. & n.d. & n.d. \\
\hline
\end{tabular}

a - preparatory phase (years from $t-7$ till $t-1$ ), $\mathrm{b}$ - the phase of the event itself (year $t$ ), $\mathrm{c}-$ the phase after the event (years from $t+1$ till $t+7$ ), n.d. - data not available.

Source: Author's own based on UNWTO reports (11 with annexes). 
Table 3. Relationship between organisation of mega sporting events and tourist inflow in various stages of the event based on UNWTO reports [11 with annexes]

\begin{tabular}{|c|c|c|c|c|c|c|c|c|c|c|}
\hline \multirow{2}{*}{ Variable } & \multicolumn{2}{|c|}{ All $(n=480)$} & \multicolumn{2}{|c|}{ SOG $(n=100)$} & \multicolumn{2}{|c|}{ WOG $(n=100)$} & \multicolumn{2}{|c|}{$\operatorname{UEFA}(n=160)$} & \multicolumn{2}{|c|}{$\operatorname{FIFA}(n=120)$} \\
\hline & Coeff. & t-Student & Coeff. & t-Student & Coeff. & t-Student & Coeff. & t-Student & Coeff. & t-Student \\
\hline Constant & 21305,9 & 1,099 & 29399,1 & $9,514^{\star * *}$ & 38057,4 & $1,930^{*}$ & 14770,2 & $15,21^{* * *}$ & 23055,6 & $6,041^{* * *}$ \\
\hline $\begin{array}{l}\text { Preparatory } \\
\text { phase }\end{array}$ & $-2683,17$ & $-0,1389$ & $-5167,44$ & $-1,070$ & $-8332,00$ & $-0,4284$ & $-1574,70$ & $-1,059$ & $-10613,6$ & $-1,893^{*}$ \\
\hline $\begin{array}{l}\text { Phase of } \\
\text { event itself }\end{array}$ & 522,267 & 0,02750 & 13,8897 & 0,001515 & $-10580,4$ & $-0,5862$ & 312,073 & 0,1087 & $-3260,97$ & $-0,2960$ \\
\hline $\begin{array}{l}\text { Phase after } \\
\text { the event }\end{array}$ & 2511,77 & 0,1291 & 532,993 & 0,1126 & $-7161,18$ & $-0,3574$ & $-936,268$ & $-0,6213$ & 3418,39 & 0,5812 \\
\hline $\begin{array}{l}\text { Period beyond } \\
\text { time window }\end{array}$ & 732,610 & 0,03771 & - & - & $-12972,2$ & $-0,6512$ & - & - & - & \\
\hline
\end{tabular}

* - statistical significance at $10 \%,{ }^{* *}$ - statistical significance at $5 \%,{ }^{* * *}$ - statistical significance at $1 \%$.

Source: Author's own.

Table 4. Relationship between organisation of mega sporting events and expenditure of tourists in various stages of the event based on UNWTO reports [11 with annexes]

\begin{tabular}{|c|c|c|c|c|c|c|c|c|c|c|}
\hline \multirow{2}{*}{ Variable } & \multicolumn{2}{|c|}{ All $(n=480)$} & \multicolumn{2}{|c|}{ SOG $(n=100)$} & \multicolumn{2}{|c|}{ WOG $(n=100)$} & \multicolumn{2}{|c|}{$\operatorname{UEFA}(n=160)$} & \multicolumn{2}{|c|}{$\operatorname{FIFA}(n=120)$} \\
\hline & Coeff. & t-Student & Coeff. & t-Student & Coeff. & $\mathrm{t}$-Student & Coeff. & t-Student & Coeff. & t-Student \\
\hline Constant & 30479,6 & 0,7925 & 61267,9 & $7,759^{\star * *}$ & 59967,2 & 1,007 & 15125,4 & $10,93^{\star * *}$ & 19370,8 & $7,624^{* * *}$ \\
\hline $\begin{array}{l}\text { Preparatory } \\
\text { phase }\end{array}$ & $-11706,2$ & $-0,3054$ & $-37577,4$ & $-3,04^{* * *}$ & $-22158,2$ & $-0,3772$ & $-6528,85$ & $-3,080^{* * *}$ & $-6799,83$ & $-1,822^{*}$ \\
\hline $\begin{array}{l}\text { Phase of } \\
\text { event itself }\end{array}$ & $-5744,43$ & $-0,1524$ & $-20030,3$ & $-0,8551$ & $-24780,0$ & $-0,4545$ & $-1765,94$ & $-0,4316$ & $-1929,94$ & $-0,2631$ \\
\hline $\begin{array}{l}\text { Phase after } \\
\text { the event }\end{array}$ & 2016,30 & 0,05223 & $-13796,8$ & $-1,141$ & $-5928,51$ & $-0,09796$ & 395,928 & 0,1844 & 6063,63 & 1,549 \\
\hline $\begin{array}{l}\text { Period beyond } \\
\text { time window }\end{array}$ & $-3,12465$ & $-8,103 e-005$ & - & - & $-23348,3$ & $-0,3880$ & - & - & - & - \\
\hline
\end{tabular}

* - statistical significance at $10 \%,{ }^{* *}$ - statistical significance at $5 \%,{ }^{* * *}$ - statistical significance at $1 \%$.

Source: Author's own.

statistically significant results, this refers to the host countries organising FIFA with regard to tourist inflow (Tab. 3). In the preparatory phase, in this case, there were over 10.6 million fewer longer-term tourists compared to the remaining period of the analysis. In terms of the expenditure of visitors (Tab. 4), lower values were found in the preparatory phase of SOG (less by 37.5 billion USD), UEFA (less by 6.5 billion USD), and again FIFA (less by 6.8 billion USD) compared with the remaining period of analysis.

\section{Discussion}

Although Dwyer et al. state that "mega sporting events allow a host country to be put on the world map" [19], the results of the research conducted do not give an unambiguous answer concerning the positive impact of these events on the tourism sector. The increased tourist flow in the years 1995-2014 should be considered a global trend, determined primarily by [20]:

- an increase in the wealth of the society;

- the development of transport infrastructure, especially with regard to roads and air transport (e.g., dynamic development of low-cost airlines);

- technological development, including of the Internet.
The organisation of mega sporting events can be treated as a factor supporting the development of tourism, although it is hard to consider it as the main factor of growth. This is confirmed by data on the dynamics of changes in the inflow of foreign tourists, contained in Table 1. In several host countries, in the time of a particularly strong inflow of tourists expected during the year of the event (in year $t$ ), a decrease was in fact noticed, compared to the last year of the preparatory phase (year $t-1)$. This may indicate the occurrence of a crowding-out effect caused by the decision of some tourists not to travel to a host country in the event year. Sometimes this was impacted by unpredictable circumstances, such as the attack on the WTC in New York in 2001 (in the case of WOG 2002).

To an even greater extent, a general upward trend was seen in terms of the expenditure of foreign tourists in host countries at the time of a mega sporting event. Such a clear increase in expenditure resulted from the continuously increasing number of visitors, the increase in their wealth, and their prolonged period of stay. Despite this, declines in the expenditure of foreign tourists have been observed in the time window of the event. Such a situation took place, among others, in the USA, which hosted SOG in 1996. Particularly worth reporting is the decline in the dynamics of spending by foreign tourists in year $t$ com- 
pared to year $t-1$ in the case of the Winter Olympic Games. In other words, in the event time window, the highest expenditure increase was observed in a year other than year $t$. This means that the organisation of a mega sporting event did not attract more funds from foreign tourists in the event year than funds that flowed into the organiser's economy in other years. According to the regression analysis, the fact that the organisation of mega sporting events had a clearly unfavourable impact on the tourism sector in the preparatory phase is also significant.

The real estimation of benefits resulting from the inflow of tourists is difficult and requires the consideration of several factors related to the geographic location of the sporting event and climate conditions, and the undertaking of a thorough analysis of the behaviour of potential fans, their habits, the scale and structure of their expenditure, and other factors [21]. It can be assumed that in the case of events such as the European Football Championships, the scale of the tourist flow in a given city is random and depends on which national teams play their matches at the location. It is in fact the visitors from these countries who will determine the tourist flow to the greatest extent [2]. On the basis of observations of mega events to date, it is possible to indicate fans who are particularly involved and follow their national teams in larger groups. These include Spanish, Dutch, Irish, and Italian fans. Greater benefits for the host result from fans visiting from wealthier countries, who are willing to spend more during their visit [22]. The geographical location of the host is also of great significance. An inflow of tourists from neighbouring countries or closely located countries should be expected to a greater extent [2]. Other considerations, such as having a single currency or using the same language, may also be considered [2].

Above all, it seems problematic to separate the organisation of sporting events from a number of other determinants which affect selected aspects of the tourism sector. In addition, it is difficult to compare individual mega sporting events, even within the same event category, in terms of the size of individual economies of host countries/regions, the level of economic development of the hosts, existing sports and non-sports infrastructure, the amount of expenditure for the organisation of events, the sources of financing for such initiatives, and other factors.

\section{Conclusions}

The results of the analysis are characterised by considerable ambiguity. The positive changes were part of a general global trend. Although mega sporting events could support these increases, growth would have likely occurred regardless of their organisation. This is confirmed by the results obtained beyond the event time windows, which were equally good or even better than the results gained during the event phases. Since it is difficult to indicate unambiguously positive, tangible effects gained by the organisation of mega sporting events, it is also problematic to justify the involvement of large expenditure in preparing and undertaking these events. Therefore, it is necessary to seek other, intangible effects of mega sporting events (image improvement, global promotion of the host country, etc.).

The interpretation of the results obtained should be approached with caution and moderation. All empirical analyses are complicated by the fact that the situation in a host's tourism industry depends on many different variables, and it is not easy to distinguish just one connected with the organisation of a mega sporting event. An attempt to assess the impact of such events always carries the danger that a complex network of cause-and-effect links shaping the state of the tourism sec- tor will be reduced to a small number of regularities. Therefore, clearly positive or negative dependencies should not be associated exclusively with the organisation of sporting events, but other, parallel causative factors should be considered.

It should not be forgotten that the organisation of mega sporting events usually takes place in one or, at most, several host country regions. It is these places that receive the greatest impact of tourism sector benefits from the organisation of events. Therefore, in order to identify the actual beneficiaries of these events, it seems reasonable to continue the research undertaken based on data disaggregated at regional levels in the future.

\section{Literature}

1. Weed M., Jackson G. (2009). The relationship between sport and tourism. In W.B. Houlihan (ed.), Sport and society. A student introduction (pp. 393-406). London: Sage.

2. Fourie J., Santana-Gallego M. (2011). The impact of megasport events on tourist arrivals. Tourism Management 32(6), 1364-1370.

3. Ahlert G., Preuss H. (2010). Experiences in estimating the macroeconomic impact of mega tourism events: The case of hosting the FIFA Football World Cup Germany 2006. Mainzer Papers on Sports Economics E Management 2.

4. Preuss H. (2007). The conceptualisation and measurement of mega sport event legacies. Journal of Sport and Tourism 12(3-4), 207-228. DOI: 10.1080/14775080701736957.

5. Masterman G. (2003). The event planning process: Strategies and successful legacies. In M. Moragas, C. Kennett, N. Puig (eds.), The legacy of Olympic Games (1984-2000) (pp. 450-489). Lausanne: Olympic Museum and Studies Centre.

6. Matheson V. (2006). Economic impact analysis. In W. Andreff, S. Szymanski (eds.), Handbook on the Economics of Sport (pp. 35-57). Cheltenham: Edward Elgar.

7. Kasimati E. (2003). Economic aspects and the Summer Olympics: A review of related research. International Journal of Tourism Research 5(6), 433-444. DOI: 10.1002/ jtr.449.

8. Zawadzki K. (2017). The economic effects of staging mega sporting events. Gdańsk: Wydawnictwo Politechniki Gdańskiej. [in Polish]

9. Pyo S., Cook R., Howell R. (1988). Summer Olympic tourism market: Learning from the past. Tourism Management 9(2), 137-144. DOI: 10.1016/0261-5177(88)90023-4.

10. Baade R. A., Matheson V. A. (2004). The quest for the Cup: Assessing the economic impact of the World Cup. Regional Studies 38(4), 343-354. DOI:10.1080/03434002000213888.

11. World Tourism Organization (2016). Methodological notes to the tourism statistics database. 2016 Edition. Madrid: UNWTO. DOI: 10.18111/9789284418541.

12. Wasilczuk J.E., Zawadzki K. (2011). Euro 2012. Can this match be won? Warszawa: CeDeWu. [in Polish]

13. Atkinson G., Mourato S., Szymanski S., Ozdemiroglu E. (2008). Are we willing to pay enough to 'back the bid'?: Valuing the intangible impacts of London's bid to host the 2012 Summer Olympic Games. Urban Studies 45(2), 419444. DOI: 10.1177/0042098007085971.

14. Gratton C., Preuss H. (2008). Maximizing Olympic impacts by building up legacies. The International Journal of the History of Sport 25(14), 1922-1938. DOI: 10.1080/09523360802439023.

15. Cornelissen S., Bob U., Swart K. (2011). Towards redefining the concept of legacy in relation to sport mega-events: Insi- 
ghts from the 2010 FIFA World Cup. Development Southern Africa 28(3), 307-318. DOI:10.1080/0376835X.2011.595990.

16. Preuss H., Weiss H. J. (2003). Torchholder value added. Der oekonomische Nutzen der Olympischen Spiele 2012 in Frankfurt Rhein/Main. Eschborn: AWV-Verlag. [in German]

17. Kang Y.S., Perdue R.R. (1994). Long-term impact of a megaevent on international tourism to the host country: A conceptual model and the case of the 1988 Seoul Olympics. Journal of International Consumer Marketing 6(3-4), 205225. DOI: 10.1300/J046v06n03_11.

18. Sterken E. (2007). Growth impact of major sporting events. In H. Preuss (ed.), The impact and evaluation of major sporting events (pp. 63-77). London/New York: Routledge.
19. Dwyer L., Forsyth P., Spurr R. (2005). Estimating the impacts of special events on an economy. Journal of Travel Research 43(4), 351-359. DOI: 10.1177/0047287505274648.

20. Pigram J.J., Wahab S. (1997). Tourism, development and growth: The challenge of sustainability. London/ New York: Routledge.

21. Maennig W., Porsche M. (2008). The feel-good effect at mega sport events: Recommendations for public and private administration informed by the experience of the FIFA World Cup 2006. IASE/NAASE Working Paper Series 08-17.

22. Ribeiro J.C., Viseu J., Dalalande T., Rodrigues C. (2004). UEFA Euro 2004 Visitor Analysis, NIPE Working Papers 15.

Submitted: September 13, 2018.

Accepted: December 7, 2018. 